Krasnov O. Counteraction to organized crime by bodies of the State Border Guard Service of Ukraine

The article discusses the main features of modern organized crime as a transnational phenomenon of a global scale that conflicts with the interests of the development of mankind as a whole. It is stated that the commission of transnational crimes by organized crime groups is a factor that determines the participation in the counteraction by the state border guards, which is reflected in the legislation of our country and the practice of the State Border Guard Service of Ukraine.

Attention is focused on the interaction of the State Border Guard Service of Ukraine with the competent authorities of other states and international organizations. This is especially true of countering cross-border crime, including smuggling, illegal migration, illegal operations with drugs, their analogues and precursors.

It is noted that the protection of the state border is implemented in the military and law enforcement spheres. It includes, among other things, counterintelligence and operational-search measures.

The author reinforces his conclusions in the article with statistical data on the results of the activities of the relevant practical bodies and their individual units. Among them are the results of joint activities in the framework of international cooperation, operations under the auspices of FRONTEX.

It is noted that a promising direction of improving the system of combating organized crime is the formation of joint operational and investigative groups. Participants in these joint groups are advisable to identify representatives of various departments.

Other promising areas for improving the anti-crime system by the State Border Guard Service of Ukraine have also been highlighted.

Key words: organized crime, law enforcement, protection of the State border, State Border Guard Service of Ukraine.

УДК 342.572

Савчук T. I. кандидат юридичних наук, старший викладач кафедри криміналістики та судової експертології факультету № 1 Харківського національного університету внутрішніх справ

(м. Харків, Україна)

Безсонна Т. Ф.

старший викладач кафедри криміналістики та судової експертології факультету № 1 ХаркіВського національного університету внутрішніх справ (м. ХаркіВ, Україна)

\title{
КРИМІНАЛІСТИЧНА ХАРАКТЕРИСТИКА ЗЛОЧИНІВ ПРОТИ ГРОМАДСЬКОЇ БЕЗПЕКИ, УЧИНЕНИХ НА ТЕРИТОРІЇ ПРОВЕДЕННЯ ОПЕРАЦІЇ ОБ'ЕДНАНИХ СИЛ
}

У статті на основі аналізу слідчої та судової практики розроблено криміналістичну характеристику злочинів проти громадської безпеки, учинених на території проведення операції Об'єднаних сил. Виділено найбільш розповсюджувані злочини проти громадської безпеки, що вчиняються на території проведення операції Об'єднаних сил. Визначено структуру криміналістичної 
характеристики злочинів проти громадської безпеки, учинених на території проведення операції Об'єднаних сил, та проаналізовано ії елементи.

Ключові слова: криміналістична характеристика, елементи криміналістичної характеристики, злочини проти громадської безпеки, операщія Об'єднаних сил, район проведення операції.

Постановка проблеми. Громадська безпека - це безпека від джерел підвищеної небезпеки, а саме: злочинних організацій, терористичних груп та інших злочинних об'єднань, зброї, предметів, що становлять підвищену небезпеку для оточення, а також вогню тощо. У районі проведення операції Об'єднаних сил указаний об'єкт кримінально-правової охорони досить часто піддається впливу злочинних елементів у спосіб учинення суспільнонебезпечних діянь, що порушують громадську (загальну) безпеку й створюють загальну небезпеку (умови) загибелі людей чи настання інших тяжких наслідків або заподіюють такі наслідки.

3 огляду на ситуацію, що складається в зоні проведення операції Об'єднаних сил, одними 3 найпоширеніших злочинів проти громадської безпеки на сьогодні є злочини, пов'язані 3 терористичною діяльністю злочинних формувань i незаконними діями 3 вогнепальною зброєю, бойовими припасами та вибуховими речовинами. Указані види злочинів в окремих випадках пов'язані між собою, проте переважна частина злочинів, передбачених ст. 263 КК, учиняється самостійно. Їх розслідування складає значні труднощі, які обумовлюються специфікою місця вчинення таких злочинів, масштабами злочинної діяльності та суб'єктним складом осіб, задіяних у їх вчиненні. Крім того, однією з проблем також є відсутність наукових рекомендацій щодо методики розслідування вказаних злочинів. Однак очевидно, що першим кроком до розробки рекомендацій щодо розслідування конкретного виду злочинів $є$ визначення та дослідження елементів їх криміналістичної характеристики, що і визначає актуальність цієї статті.

Аналіз останніх досліджень і публікацій. Теоретичне дослідження положень криміналістичної характеристики злочинів проводили такі вченікриміналісти, як В. П. Бахін, Р. С. Бєлкін, О. О. Ейсман, О. Н. Колесніченко, Н. І. Клименко, В. С. Коновалова, І. Ф. Крилов, В. С. Кузьмичов, В. Г. Лукашевич,

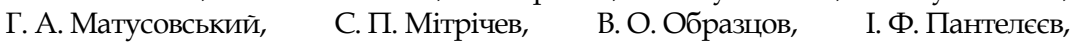
М. В. Салтевський, М. О. Селіванов, Л. О. Сергєев, А. В. Старушкевич, В. Г. Танасевич, М. П. Яблоков, Н. А. Якубович та багато інших. Попри значний унесок, зроблений ученими 3 досліджуваного питання, у криміналістичній літературі відсутня криміналістична характеристика злочинів проти громадської безпеки, учинених у зоні проведення операції Об'єднаних сил.

Формування цілей. Метою статті є розробка та дослідження окремих елементів криміналістичної характеристики злочинів проти громадської безпеки, учинених в зоні проведення операції Об'єднаних сил.

Виклад основного матеріалу. Криміналістична характеристика злочину є теоретичною категорією криміналістики, яка відноситься до злочину як до події, що спричинила певні зміни в навколишньому 
середовищі [1, с. 375]. О.Н.Колесніченко та В. О. Коновалова визначали криміналістичну характеристику як систему інформації про ознаки злочинів цього виду, що мають криміналістичне значення, відзначають закономірні зв' язки між ними і слугують побудові та перевірці слідчих версій для вирішення завдань розслідування [2, с. 16]. Своєю чергою М. В. Салтевський пропонував визначати криміналістичну характеристику як інформаційну модель, що становить собою якісно-кількісну систему опису типових ознак конкретного виду (групи) злочинів [3, с. 267]. Схожої думки дотримувався В. П. Бахін, який розглядав ї̈ як систему узагальнених даних про найбільш типові ознаки певного виду (групи) злочинів, які слугують основою наукового й практичного вирішення завдань розкриття та розслідування злочинів [4, с. 179]. Проте вчені не вказали наявності закономірних зв'язків між такими ознаками, що вбачається суттєвим упущенням. Дещо іншу думку висловлює О. В. Кузнєцова, стверджуючи, що криміналістична характеристика злочину є інформаційною моделлю, яка об'єднує сукупність систематизованих і типізованих відомостей про таку подію й пов'язані з нею процеси, а також закономірності їх відображення та джерела відображеної інформації [1, с. 375]. Отже, переважна кількість учених-криміналістів сходяться на тому, що криміналістична характеристика окремого виду злочинів це, зокрема, наукова категорія, покликана вирішувати завдання розслідування як на науковому, так і на практичному рівнях. Вона являє собою систематизовану інформацію про ознаки окремого виду злочинів або елементи механізму його вчинення та відображає закономірні зв'язки між такими елементами і слугує для висунення криміналістичних версій та вирішення завдань розслідування.

У криміналістичній літературі немає єдності й у визначенні змісту криміналістичної характеристики. Так, Р. С. Бєлкін зазначав, що криміналістична характеристика окремого виду злочину має містити характеристику вихідної інформації; систему відомостей про спосіб учинення та приховання злочинів і типові наслідки його застосування, особу ймовірного злочинця та ймовірні мотиви і цілі злочину, особу ймовірної жертви злочину, а також деякі обставини вчинення злочину (місце, час, обстановку) [5, с. 736]. А. В. Старушкевич, указуючи, що під криміналістичною характеристикою злочинів можна розуміти певним чином упорядковану сукупність даних (відомостей) про криміналістично значимі ознаки злочинів, наголошує, що кожний злочин має багато різних ознак. Одні з них мають значення для кримінально-правової кваліфікації злочину, правильного вирішення кримінальної справи, інші - для прийняття кримінально-процесуальних рішень, треті - для розкриття та розслідування тощо [6, с. 8]. Отже, указана сукупність даних стосується тих чи інших елементів механізму злочину. Тобто зміст криміналістичної характеристики того чи іншого виду злочинів складають дані про конкретні елементи механізму злочину.

Свого часу I. Ф. Пантелєєв до криміналістичної характеристики конкретного виду злочинів відніс типові ситуації цього виду злочину, найбільш розповсюджені способи їх учинення, технічні засоби, які 
застосовує злочинець для вчинення злочину, характеристику типових матеріальних слідів злочину, які можуть мати значення речових доказів, найбільш ймовірні місця їх виявлення, тайники, способи приховання слідів злочину та інших засобів маскування злочинців, характеристика їхніх професійних злочинних навиків, злочинних звуків тощо [7, с. 359].

Неодноразово робилися спроби узагальнити думки 3 цього питання, висловлені в криміналістичній літературі. Зокрема, М.В.Салтевський, розглянувши всі елементи, дійшов висновку про те, що більшість авторів виділяють чотири основних іï елементи: предмет безпосереднього посягання, спосіб учинення злочину в його широкому розумінні, типову обстановку - «слідову картину» в ії широкій інтерпретації, особу злочинця [8, с. 419]. Уявляється, що запропонована узагальнена система елементів криміналістичної характеристики є типовою для більшості злочинів. Проте при побудові криміналістичної характеристики окремого виду злочину мають враховуватися й інші елементи, такі, наприклад, як особа жертви (потерпілого), окремі обставини вчинення злочину (час, місце та обстановка) тощо.

Зауважимо, що всі елементи криміналістичної характеристики злочину взаємозалежні, а виявлення внутрішніх зв'язків дає змогу, пізнаючи один елемент системи злочину, одержати знання про деякі інші елементи i, зрештою, розкрити злочин [9, с. 45]. Тому при розробці криміналістичної характеристики мають враховуватися такі закономірності, адже вони дають основу для висунення окремих версій за тими чи іншими елементами механізму злочину.

3 огляду на викладене констатуємо, що криміналістична характеристика злочинів, учинених в зоні проведення операції Об'єднаних сил має охоплювати дані про способи злочину, особу злочинця та потерпілого, обставини вчинення злочинів (час, місце та обстановка), типові сліди злочинів.

Як уже зазначалося, найбільш розповсюдженими злочинами проти громадської безпеки, що вчиняються на території проведення операції Об'єднаних сил, є злочини терористичної спрямованості, або інакше кажучи ті, які пов'язані 3 терористичною діяльність злочинних формувань. Відповідно до Закону України «Про боротьбу з тероризмом» терористичною визнається діяльність, яка охоплює:

а) планування, організацію, підготовку та реалізацію терористичних актів;

б) підбурювання до вчинення терористичних актів, насильства над фізичними особами або організаціями, знищення матеріальних об'єктів у терористичних цілях;

в) організацію незаконних збройних формувань, злочинних угруповань (злочинних організацій), організованих злочинних груп для вчинення терористичних актів, так само як і участь у таких актах;

г) вербування, озброєння, підготовку та використання терористів;

г) пропаганду й поширення ідеології тероризму;

д) фінансування та інше сприяння тероризму [10].

Зокрема, злочини терористичної спрямованості вчиняються способами, які охоплюють дії з підготовки, безпосереднього вчинення та приховання їх слідів. Дії з підготовки до вчинення таких злочинів передбачають: 
- визначення об'єкта посягання;

- визначення найбільш оптимального способу вчинення злочину;

- визначення часу та місця вчинення злочину, а за необхідності підготовка вказаного місця до вчинення злочину в спосіб пошкодження замків, сигналізації, пожежних щитів тощо;

- підшукання співучасників серед прибічників злочинних поглядів, службових осіб через переконання, залякування, підкуп тощо;

- за необхідності отримання грошових і матеріальних активів для здійснення злочинної діяльності;

- підшукання та підготовку зброї, боєприпасів, вибухових речовин, а також їх пристосування до обстановки вчинення злочину;

- в окремих випадках підготовку агітаційної продукції та їі розповсюдження;

- підготовку транспортних засобів та шляхів підходу і відходу злочинців на місці вчинення злочину;

- підготовку, а в деяких випадках розробку засобів маскування для злочинців (одягу, екіпірування, взуття тощо) та для знарядь учинення злочину (вибухових пристроїв, зброї, військової техніки) тощо;

- визначення способів і підготовку засобів приведення в готовність вибухових пристроїв;

- розробку плану заходів опору та протистояння працівникам правоохоронних органів України та Збройних сил України тощо.

Безпосереднє вчинення злочинів терористичної спрямованості в районі проведення операції Об'єднаних сил характеризується здійсненням: 1) підривів стратегічних об'єктів (вокзалів, заводів, підприємств, установ та організацій, мостів і трубопроводів); 2) підривів житла та транспортних засобів посадових осіб органів державної влади та місцевого самоврядування, а також співробітників правоохоронних органів і військових формувань; 3) організацією вибухів під час масових заходів; 4) нападу на гуманітарні місії та спостерігачів міжнародних організацій; 5) організацією та веденням збройного опору, незаконної протидії та перешкоджання виконанню службових обов'язків співробітниками правоохоронних органів України і військовослужбовцями Збройних сил України, задіяними в проведенні операції Об'єднаних сил на території Донецької та Луганської областей України; 6) опору представникам державної влади та унеможливлення припинення злочинної діяльності правоохоронними органами та ЗС України.

Для вчинення вказаних злочинів використовується вогнепальна зброя, боєприпаси та вибухові пристрої, речовини, військова техніка, що були викрадені зі складських приміщень правоохоронних органів і військових частин, а також ввезені на підконтрольну територію України з непідконтрольних територій та 3 інших держав. Крім того, частину вибухових пристроїв виготовляють самостійно злочинщі або пристосовують до умов учинення злочину.

Характерною особливістю вказаних злочинів є те, що вони вчиняються діючими або колишніми службовими особами органів державної влади, 
місцевого самоврядування, правоохоронних органів та військовослужбовцями. Це пов'язано з тим, що саме вказані особи мають фізичну можливість створення терористичних організацій і вчинення терористичних актів, адже в їхньому розпорядженні є достатня кількість зброї, боєприпасів, вибухових речовин, фізично підготовлені особи, які можуть бути схилені до вчинення злочинів, а також саме вони обізнані в оперативній обстановці в регіоні та об'єктах підвищеної охорони. Однак до складу груп також часто входять місцеві жителі як із підконтрольної Україні території, так і з непідконтрольної, які підтримують погляди терористичної організації, або які отримали матеріальну винагороду за участь у терористичній діяльності.

Указані терористичні організації характеризуються чітким розподілом ролей, адже мають організаційну структуру військового типу (поділяються на структурні підрозділи з визначенням особового складу кожного 3 них, який носить формений одяг військового типу), характеризуються наявністю єдиноначальності та субординації, використанням знаків розрізнення, мають воєнізований характер завдань і методів (здійснення з використанням вогнепальної зброї та військової техніки збройного опору підрозділам Збройних сил України та інших військових формувань України, задіяних у проведенні операції Об'єднаних сил на території Донецької та Луганської областей України) та ставлять перед собою специфічні завдання (утримання території окремих районів Донецької та Луганської областей, тимчасово не підконтрольних органам державної влади України, встановлення на території цих районів військового стану) та мають для цього відповідні матеріальні засоби (вогнепальну зброю - автомати, міномети), також військову техніку.

Небезпека вчинення злочинів терористичної спрямованості полягає в тому, що їх жертвами стають не лише особи, на яких спрямований злочинний умисел, але й інші випадкові цивільні особи, серед яких часто страждають діти, жінки та особи похилого віку.

Час вчинення таких злочинів залежить від спрямованості умислу та способу вчинення. Зокрема, якщо умисел спрямований на пошкодження об'єктів, то досить часто злочинці обирають нічний час, коли на об'єктах невелика кількість людей. Однак, якщо злочинний умисел спрямований на завдання якнайбільшої шкоди життю та здоров'ю людей для створення гучного резонансу, то обирається час та місце, коли на об'єкті є найбільша їхня концентрація. Вказане правило діє й під час організації вибухів на масових заходах.

Дещо по-іншому визначається час учинення підриву житла чи транспортних засобів окремих осіб. У цьому випадку враховується темп життя особи та спрямованість злочину (налякати, завдати шкоди здоров'ю або ж позбавити життя) і обирається найбільш сприятливий момент вибуху.

Сліди вказаних злочинів досить різноманітні та залежать значно від обраного способу вчинення злочину. Проте очевидно, що ці злочини залишають як сліди матеріального походження (знаряддя вчинення злочину та їх частини, тілесні ушкодження на потерпілих, агітаційна продукція, 
зруйновані об'єкти тощо), так і сліди ідеального походження (які містяться в показаннях свідків, потерпілих, підозрюваних).

Зі злочинами терористичної спрямованості досить тісно пов'язані злочини, які стосуються незаконних дій зі зброєю, бойовими припасами та вибуховими речовинами. В окремих випадках вони стають необхідною умовою вчинення попередніх злочинів, або незаконно отримана зброя використовується для вчинення інших злочинів, проти життя та здоров'я, власності, громадського порядку та моральності тощо. Проте з огляду на ситуацію, яка на сьогодні склалася в зоні проведення операції Об'єднаних сил, переважна кількість злочинів, передбачених ст. 263 КК України вчиняється й без наміру дальшого використання такої зброї у злочинних цілях.

Способами вчинення незаконного поводження з вогнепальною зброєю, боєприпасами та вибуховими речовинами є:

- незаконне оплатне придбання та зберігання вогнепальної зброї, боєприпасів і вибухових речовин;

- незаконне безоплатне придбання вогнепальної зброї, боєприпасів та вибухових речовин;

- виявлення вогнепальної зброї, боєприпасів і вибухових речовин на території проведення військових дій та незаконне їх зберігання;

- розбирання та ремонт виявленої на місці проведення військових дій зброї, боєприпасів і вибухових речовин;

- виявлення та зберігання нерозірваних боєприпасів;

- збут вогнепальної зброї, боєприпасів та вибухових речовин;

- придбання, зберігання та збут холодної зброї тощо.

Предметом злочинного посягання найчастіше є:

- ручна вогнепальна зброя (пістолети, рушниці, автомати, кулемети, міномети тощо);

- боєприпаси до вогнепальної зброї та ручні гранати;

- вибухові пристрої та речовини як заводського, так саморобного способів виготовлення;

- холодна зброя (кинджали, фінські ножі, кастети тощо).

Особою злочинця здебільшого є неповнолітні та повнолітні чоловіки. За характером вони легковажні, безпечні, самовпевнені. Частина таких осіб має навички поводження зі зброєю. У деяких випадках такі особи перебували в стані сп'яніння. Характерною особливістю вказаних злочинів для зони проведення операції Об'єднаних сил є те, що вони можуть вчинятися й військовослужбовцями. Однак у такому разі незаконне поводження поєднано із привласненням військовослужбовцем бойових припасів і вибухових речовин (ст. 410 КК України). Такі особи досить часто заволодівають зброєю та боєприпасами для переміщення до місця проживання як трофею або 3 корисливою метою для реалізації третім особам.

Час учинення злочинів, передбачених ст. 263 КК характеризується тим, що він переважно збігається з часом закінчення обстрілів на відповідній території або бойових дій чи розмінуванням території. Досить часто злочинці виявляють зброю та боєприпаси на покинутих блокпостах, місцях 
дислокації військових формувань, на території населених пунктів, доріг або навіть поблизу власних дворів чи будівель у військових частинах.

Головна небезпека від учинення вказаних злочинів полягає в тому, що досить часто такі особи, не знаючи правил поводження із вогнепальною зброєю, боєприпасами та вибуховими речовинами, необережно завдають шкоду як власному здоров' ю або життю, так й іншим особам. Окрім того, зброя та боєприпаси можуть бути використані для вчинення злочинів різних видів.

Висновки. Отже, визначення та дослідження елементів криміналістичної характеристики злочинів проти громадського порядку, учинених в зоні проведення операції Об'єднаних сил, є першим кроком до розробки рекомендацій щодо розслідування цих видів злочинів. При формуванні криміналістичної характеристики вказаних злочинів потрібно враховувати специфіку регіону та загальну структуру криміналістичної характеристики. 3 урахуванням розробленої криміналістичної характеристики в перспективі мають бути розроблені рекомендації 3 розслідування злочинів проти громадської безпеки, учинених на території проведення операції Об'єднаних сил (на територіях Донецької та Луганської областей).

\section{Використані джерела:}

1. Кузнєцова О. В. До питання щодо поняття та структури криміналістичної характеристики злочинів. Актуальні проблеми права: теорія і практика. 2010. № 18. C. 372-376. URL: http:/ / nbuv.gov.ua (дата звернення : 14.12.2018).

2. Колесниченко О. Н., Коновалова В.О.Криминалистическая характеристика преступлений : учебное пособие. Харьков: Юрид. институт, 1985. 92 с.

3. Салтевський М. В. Криміналістика : підручник : у 2 ч. Ч. 2. Харків: Консум, 2001. 528 c.

4. Бахин В. П. Криминалистика. Проблемы и мнения (1962-2002) : монография. Киев, 2002. 268 с.

5. Белкин Р. С. Курс криминалистики : учебное пособие. Москва: ЮНИТИДАНА, Закон и право, 2001. 837 с.

6. Старушкевич А. В. Криміналістична характеристика злочинів : навчальний посібник. Київ: Правник-НАВСУ, 1997. 44 с.

7. Пантелеев И. Ф., Селиванов Н. А. Криминалистика : учебник. Москва : Юрид. лит., 1975. 544 с.

8. Салтевський М. В. Криміналістика (у сучасному викладі) : підручник. Київ: Кондор, 2006. 588 с.

9. Густов Г. А. Понятие и виды криминалистической характеристики преступлений. Криминалистическая характеристика преступлений. Сб. науч. тр. Москва, 1984. С.43-48.

10. Про боротьбу з тероризмом : закон від 20.03.2003 № 638-IV. Відомості Верховної Ради України. 2003. № 25. Ст. 180 // БД «Законодавство України» / ВР України. URL: http://zakon2.rada.gov.ua/laws/show/638-15 (дата звернення: 20.12.2018). 
Савчук Т. И., кандидат юридических наук, старший преподаватель кафедры криминалистики и судебной экспертологии факультета № 1 Харьковского национального университета внутренних дел (г. Харьков, Украина)

Бессонная Т. Ф., старший преподаватель кафедры криминалистики и судебной экспертологии факультета № 1 Харьковского национального университета внутренних дел (г. Харьков, Украина)

Криминалистическая характеристика преступлений против общественной безопасности, совершенных на территории проведения операции Объединенных сил

В статье на основе анализа следственной и судебной практики разработана криминалистическая характеристика преступлений против общественной безопасности, совершенных на территории проведения операции Объединенных сил. Выделены наиболее распространяемые преступления против общественной безопасности, совершаемые на территории проведения операции Объединенных сил. Определена структура криминалистической характеристики преступлений против общественной безопасности, совершенных на территории проведения операции Объединенных сил, и проанализированы ее элементы.

Ключевые слова: криминалистическая характеристика, элементы криминалистической характеристики, преступления против общественной безопасности, операция Объединенных сил, район проведения операции.

Savchuk T., Bezsonna T. Forensic Characteristics of Crimes against Public Safety Committed on the Territory of the Joint Forces Operation

The article analyzes the scientific opinions of criminologists on the concept and structure of forensic characteristics of crimes. It has been determined that the forensic characteristic is a systematic information about the features of a particular type of crime or elements of the mechanism of its commission, and reflects the logical connections between such elements and serves for the advancement of forensic versions and solving the tasks of the investigation. The content of forensic characteristics of one or another type of crime is data on specific elements of the mechanism of the crime. It is emphasized that all elements of the forensic character of the crime are interdependent and there are regular relationships that must be taken into account when they are studied. It is determined that when constructing forensic characteristics of a particular type of crime, one must take into account not only the general structure of forensic characteristics, but also the characteristic features of a specific type of crime.

The most widespread crimes against public security committed on the territory of the operation of the united forces are allocated. On the basis of the analysis of investigative and judicial practice, a forensic description of crimes against public safety developed in the area of the operation of the combined forces was developed. The structure of the forensic characterization of crimes against public security committed on the territory of the operation of the combined forces was determined. It should include data on the methods of crime, the identity of the offender and the victim, the circumstances of the commission of crimes (time, place and circumstances), typical traces of the crime. The main elements of forensic characteristics of these crimes are analyzed.

Key words: forensic characteristic, elements of forensic characteristics, crimes against public safety, operation of United Forces, area of operation. 